\title{
REPUTASI PERUSAHAAN DALAM CARA PANDANG ONTOLOGI
}

\author{
V. Mardi Widyadmono \\ Mahasiswa Program DoktorIlmuEkonomi,UniversitasSebelasMaret Surakarta \\ StafPengajarUniversitasSanata Dharma Yogyakarta \\ v_mardi_w@yahoo.com; v_mardi_w@student.uns.ac.id \\ MugiHarsono \\ Staf PengajarUniversitasSebelasMaret Surakarta \\ Mugiharsono_fe@staff.uns.ac.id
}

\begin{abstract}
Corporate reputation is abusiness buzzword that attracts the scholars and practisioners attention in the last decade. This paper discusses dan provides argumentation on the popularity of corporate reputation by reviewing the publication addressing this theme at JSTOR, highlights the dynamic aspect of corporate reputation through quoting the Forbes rank during 2016-2018 and finally, we conclude based on ontology objective and subjective perspective, that a reputation is not an aggregation of all stakeholder's perception on it. The aggregation of perception on corporate reputation might be performed for a certain corporate stakeholder.The contribution of this paper is to help researchers developing measurement for reputation of a corporate.
\end{abstract}

Keyword: Corporate reputation, ontology, stakeholder analysis

\begin{abstract}
Abstrak
Reputasi perusahaan (Corporate reputation) adalah sebuah jargon bisnis yang saat ini mendapatkan perhatian dari akademisi dan praktisi. Paper ini mendiskusikan dan memberikan argumentasi mengenai sifat populer, melalui tinjauan publikasi mengenai corporate reputation di JSTOR, menonjolkan sifat dinamis dengan mengolah perangkingan Forbes dari tahun 2016-2018 dan akhirnya penulis menyimpulkan berdasarkan pandangan ontologi obyektif dan subyektif dengan berdasarkan teori stakeholder bahwa persepsi mengenai reputasi perusahaan bukanlah merupakan agregasi dari keseluruhan stakeholder. Agregasi mengenai persepsi reputasi hanya mungkin dilakukan pada kelompok pemangku kepentingan

saja.Temuaniniberkontribusiuntukmenyusunpengukuranreputasiperusahaandalamkerangkako ntekspenelitianreputasiperusahaan yang lebihkomprehensif.
\end{abstract}

Keyword: Corporate reputation, ontology, stakeholder analysis 


\section{PENDAHULUAN}

\section{Corporate}

reputationadalahbukanistilahbarutetapime merlukanpenjelasanuntukmendapatkanpe mahaman yang sama(Kobrak, 2013; Olegario \& McKenna, 2013). Terminologiiniketikasampai di Indonesia, orang mengalihbahasakannya sebagaireputasiperusahaan.Tampaknya kata reputasi sudah menjadi kata yang biasa dijumpai dalam masyarakat.Dalam KBBI (KamusBesarBahasa Indonesia) daring (https://kbbi.kemdikbud.go.id) kata reputasimendapatkan maknasebagai "perbuatandansebagainyasebagaisebabmen dapatnamabaik; namabaik". Nama baik ini adalah akibat dari suatu perbuatan. Oleh karenanya, membahas reputasi berarti membahas mengenai perbuatan yang menyebabkan suatu entitas mendapatkan nama

baik.

Definisiinimasihmemerlukanpenjelasanleb ihlanjutuntukmendapatkanpemahaman.Dal ambahasaInggris,

kamus

Webstermemberikandefinisi yang pertamasebagai (https://www.merriamwebster.com/dictionary/reputation): pertama, "overall quality or character as seen or judged by people in general" (keseluruhankualitasataukarakter yang secaraumumdilihatataudinilaioleh orang), dan kedua, "recognition by other people of some characteristic or ability" (pengakuandari orang lain mengenaikarakteristikataukemampuan).

Ditilikdariasalkatanya "reputatio reputare", bahasa latin, yang bermaknasebagaipertimbangan.

Dengandemikian, tampaksedikitlebihjelasbahwareputasimem ilikimaknapenilaian/pengakuan/pertimban ganatassesuatukarakterataukemampuan.

Untuk memahami konsep reputasi perusahaan, Olegario dan McKenna (2013) membawa kita melihat perjalanan konsep reputasi dalam bisnis. Dalam situasi ketidakpastian mengenai reputasi perusahaan, sering kali orang melihat pada orang kunci di dalam bisnis. Sebagai contoh, kita lebih mudah bertransaksi bisnis dengan suatu entitas bisnis baru, bila kita mengenal karakter pemilik perusahaan itu. Karakter yang dimaksudkan oleh Olegario adalah integritas dan keterbukaan. Adanya karakter ini di dalam diri pemilik perusahaan, maka akan meningkatkan kepercayaan orang untuk bertransaksi dengan perusahaan.

Fombrundan

Ponzi(2015) mendefinisikan Corporate reputation sebagai " $a$ collective assessment of a company's attractiveness to a specifi $c$ group of stakeholders relative to a reference group of companies with which the company competes for resources. "(Penilaiankolektifmengenaiday atarikperusahaanbagikelompokpemangkuk 
epentingantertenturelatifdibandingkandeng ankelompokperusahaanreferensidalam memperebutkan sumberdaya).DefinisiFombrunini memilikitiga ide pokok. Pertama, perusahaanmemilikibanyakreputasi, tergantungpadastakeholder yang dipertimbangkan.Kedua, reputasiperusahaanmerupakankonstrukper bandingan, karenaperusahaanselaludinilaidalamrelasin yadenganperusahaan lain (pesaing).Ketiga, reputasiperusahaanmerupakansumberkeun ggulankompetitifataukelemahanperusahaa n.

\section{Popularitas Reputasi Perusahaan}

Terminologi reputasi perusahaan, semakin hari semakin menjadi perhatian ilmuwan dan praktisi, sehingga Gardberg (2017)mempertanyakan apakah reputasi perusahaan itu sekedar fashion ataukah fenomena. Dari risetnya, Gadberg memastikan bahwa reputasi perusahaan merupakan fenomena di antara para akademisi dan praktisi, dan bukan sekedar fashion yang akan segera pudar dalam waktu yang singkat. Keyakinan Gardberg ternyata didukung oleh riset yang dilakukan oleh peneliti pada terbitan periode1964-2018. Denganmenggunakan kata kunci "corporate+reputation" darijurnal-jurnal yang dipublikasikan di
JSTOR, peneliti merangkumkan semua terbitan dalam tabel 1 berikut ini.

Tabel 1

Jumlah Terbitan di Jurnal

\begin{tabular}{|l|r|}
\hline Rentang & JSTOR \\
\hline $2008-2018$ & 638 \\
\hline $1997-2007$ & 329 \\
\hline $1986-1996$ & 58 \\
\hline $1975-1985$ & 8 \\
\hline $1964-1974$ & 6 \\
\hline
\end{tabular}

Tabel di atas menunjukkanpeningkatan yang

signifikanpertumbuhanpublikasimengenair $\begin{array}{lll}\text { eputasi } & \text { perusahaan. }\end{array}$ inimenguatkanbahwasemakinbanyakpemer hatipentingnyareputasi

perusahaanbagisebuahperusahaanatauorga nisasi(Brammer dan Pavelin, 2004).Bukan tanpa alasan perhatian pada isu reputasi perusahaanmeningkat di dua dekade belakang ini. Irmaini(2011)misalnya, menyebutkan bahwa perusahaanberpeluang memuaskan pelanggan, menciptakan pelanggan baru, mencapai brand positioning yang handal, penciptaan proses bisnis yang inovatif, menarik calon tenaga ahli, dan jaminan legal dari pemerintah dengan dengan reputasinya.

Adalah penting bagi semua organisasi untuk mendapatkan reputasi positif guna mendapatkan semua manfaat yang 
ditawarkan. Bahkan dari aspek persaingan, reputasi perusahaan dapat menjadi sumber keunggulan kompetitif dibandingkan dengan perusahaan pesaing(Roberts \&Dowling, 2002). Dalam posisi ini, corporate reputation masuk menjadi wilayah strategik di dalam pengelolaan organisasi. Organisasi harus merancangkan bagaimana reputasi positif itu dapat dibangun, dipertahankan dan dikembangkan.
Hasil penilai/perangkingan perusahaan di dunia berdasarkan reputasinya dilakukan oleh majalah Forbes(www.forbes.com). Dari 100 perusahaan di dunia yang diranking oleh Forbes dengan menggunakan The RepTrak Pulse system sejak tahun tiga tahun terakhir (2016-2018) mencerminkan variabilitas pandangan stakeholder terhadap perusahaan. Berikut ini adalah ranking dari 25 perusahaan berdasarkan reputasi dari tahun 2016-2018.

Tabel II

Ranking Reputasi perusahaan versi Majalah FORBES 2016-2018

\begin{tabular}{|c|c|c|c|c|c|c|c|c|}
\hline 2016 & Nama Perusahaan & Skor & 2017 & $\begin{array}{l}\text { Nama } \\
\text { Perusahaan }\end{array}$ & Skor & 2018 & Nama Perusahaan & Skor \\
\hline 1 & Rolex & 78.04 & 1 & Rolex & 80.38 & 1 & Rolex & 79.03 \\
\hline 2 & $\begin{array}{l}\text { The Walt Disney } \\
\text { Company }\end{array}$ & 78.02 & 2 & LEGO Group & 79.46 & 2 & LEGO & 77.09 \\
\hline 3 & Google & 78.01 & 3 & $\begin{array}{l}\text { The Walt Disney } \\
\text { Company }\end{array}$ & 79.19 & 3 & Google & 77.07 \\
\hline 4 & BMW Group & 77.09 & 4 & Canon & 78.28 & 4 & Canon & 77.04 \\
\hline 5 & $\begin{array}{l}\text { Daimler (Mercedes- } \\
\text { Benz) }\end{array}$ & 77.07 & 5 & Google & 78.22 & 5 & $\begin{array}{l}\text { The Walt Disney } \\
\text { Company }\end{array}$ & 77.04 \\
\hline 6 & LEGO Group & 77.04 & 6 & Bosch & 78.13 & 6 & Sony & 77.03 \\
\hline 7 & Microsoft & 77 & 7 & Sony & 77.74 & 7 & Adidas & 76.06 \\
\hline 8 & Canon & 76.09 & 8 & Intel & 77.74 & 8 & Bosch & 76.04 \\
\hline 9 & Sony & 76.07 & 9 & $\begin{array}{l}\text { Rolls-Royce } \\
\text { Aerospace }\end{array}$ & 77.66 & 9 & BMW Group & 76.01 \\
\hline 10 & Apple & 76.06 & 10 & Adidas & 77.27 & 10 & Microsoft & 75.08 \\
\hline 11 & Intel & 76.04 & 11 & Microsoft & 77.12 & 11 & Michelin & 75.07 \\
\hline 12 & Adidas Group & 76.01 & 12 & BMW Group & 76.93 & 12 & Nike & 75 \\
\hline 13 & Nike & 75.09 & 13 & Michelin & 76.75 & 13 & Nintendo & 74.05 \\
\hline 14 & $\begin{array}{l}\text { Rolls-Royce } \\
\text { Aerospace }\end{array}$ & 75.08 & 14 & $\begin{array}{l}\text { Levi Strauss \& } \\
\text { Co. }\end{array}$ & 76.70 & 14 & Levi Strauss \& Co. & 74.04 \\
\hline 15 & Michelin & 75.07 & 15 & Nike, Inc. & 75.74 & 15 & Intel & 74.03 \\
\hline
\end{tabular}




\begin{tabular}{|l|l|l|l|l|l|l|l|l|}
\hline 16 & Johnson \& Johnson & 75.02 & 16 & Nintendo & 75.72 & 16 & Goodyear & 74 \\
\hline 17 & Samsung Electronics & 75 & 17 & Ferrero & 75.45 & 17 & Rolls-Royce & 74 \\
\hline 18 & Ferrero & 74.08 & 18 & Amazon.com & 75.33 & 18 & Ferrero & 74 \\
\hline 19 & Nintendo & 74.07 & 19 & IBM & 75.29 & 19 & Philips & 73.08 \\
\hline 20 & Levi Strauss \& Co. & 74.03 & 20 & Apple & 74.94 & 20 & Bridgestone & 73.07 \\
\hline 21 & Amazon.com & 74.03 & 21 & Philips & 74.94 & 21 & Visa & 73.06 \\
& & & & Electronics & & & & 73.05 \\
\hline 22 & Nestlé & 74 & 22 & 3 M & 74.82 & 22 & Giorgio Armani & 73.05 \\
\hline 23 & Philips Electronics & 73.08 & 23 & Barilla & 74.74 & 23 & Amazon & 73.03 \\
\hline 24 & L'Oréal & 73.07 & 24 & Cisco Systems & 74.72 & 24 & Netflix & 73.03 \\
\hline 25 & Robert Bosch & 73.07 & 25 & Colgate- & 74.64 & 25 & 3 M & \\
\hline
\end{tabular}

Data diolah dari Forbes.com

Variabilitas reputasi perusahaan yang tercermin dari perubahan posisi peringkat dapat digolongkandalam empat kategori umum:

1. Ranking selalu meningkat

2. Ranking selalu turun

3. Ranking mengalami naik dan turun, dan

4. Ranking tetap.

Ringkasan variabilitas reputasiversi Forbes dari 2016-2018 ditunjukkan dalam tabel III.

\section{Tabel III}

Perubahan Posisi Reputasi Perusahaan 2006-2018

\begin{tabular}{|l|l|l|l|l|}
\hline No & Posisitetap & Posisinaik & Posisiturun & Posisinaik- turun \\
\hline 1 & Rolex & LEGO Group & The Walt Disney Company & Google \\
\hline 2 & & Canon & BMW Group & Nike \\
\hline 3 & & Sony & Daimler (Mercedes-Benz) & Intel \\
\hline 4 & & Adidas Group & Microsoft & Rolls-Royce Aerospace \\
\hline 5 & & Michelin & Apple & Ferrero \\
\hline 6 & & Nintendo & Johnson \& Johnson & Amazon.com \\
\hline 7 & & Levi Strauss \& Co. & Samsung Electronics & Robert Bosch \\
\hline 8 & & Philips Electronics & Nestlé & \\
\hline 9 & & & L'Oréal & \\
\hline
\end{tabular}

Perubahan ranking perusahaan dalam tabel III, menggambarkan bahwa reputasi merupakan atribut yang dinamis. Ada perusahaan yang mengalami kenaikan selama tiga tahun berturut-turut (misalnya, Lego group, Canon, Sony, Adidas Group). 
Adapula perusahaan yang merasakanpengalaman turun peringkat selama tiga tahun berturut-turut (misalnya The Walt Disney, BMW group, Daimler, Microsoft, Apple, Johnson \& Johnson). Sementara Google, Nike, Intel Roll-Royce Aerospace, Ferrero, dan Amazon adalah beberapa perusahaan yang mengalami naik dan turun pada ranking reputasinya. Forbes menggunakan konsumen, pihak eksternal bagi perusahaan, sebagai responden untuk menilai reputasi perusahaan.

Pèrez(2015)dan

Gardberg (2017)mengatakan reputasi perusahaan adalah aset tak berwujud. Artinya reputasi perusahaan bersifat tahan lama (durable) dan kuat (resistant) terhadap tekanan pesaingan dibandingkan dengan atributbarang dan jasa (Illia dan Ballmer, 2012) dan reputasi perusahaan memfasilitasi perusahaan memperoleh keunggulan kompetitif (Luijk, 2003; Quevedo-puente, Fuente-sabat, \& Delgado-Garcia, 2003). Seandainya pendapat Perez ini benar, muncul pertanyaan mengapa reputasi perusahaan mengalami pasang surut seperti tercermin dalam ranking dari Forbes. Ada dua cara untuk memahami hal ini. Penjelasan pertama, perusahaan dapat saja tidak mengelola reputasi perusahaan karena reputasi perusahaan dianggap ditentukan oleh pihak eksternal. Spekulasi ini datang karena Forbes menggunakan pihak eksternal di dalam melakukan perangkingannya. Penjelasan kedua, perusahaan mungkin lebih menonjolkan reputasi pada produk tetapi tidak pada reputasi perusahaan sebagai satu entitas. Dari aspek pemasaran, kita mengenal terminologi citra merek atau brand image, yang pada umumnya merupakan atribut produk. Dengan terminologi ini, maka perusahaan terdorong untuk fokus pada produk-produk unggulan perusahaan. Kita mengenalnya dengan istilah flagship. Produk dengan merek tertentu atau seri tertentu dijadikan produk unggulan guna menaikkan jumlah permintaan pasar.

Perez (2015)membedakan elemen reputasi perusahaan yaitu aspek kognitif dan aspek emosional. Aspek kognitif merujuk pada keyakinan atau penilaian (yang dapat positif atau negatif) dan mengidentifikasikan reputasisebagai persepsi atas kepribadian/temperamen organisasi (organizatinal personality). Sementara aspek emosional berkenaan dengan perasaan atau sikap, misalnya kepercayaan dan tingkat penghargaan atau kekaguman pemangku kepentingan pada perusahaan. Dengan dasar teori reasoned action yang digunakan Perez, tampak bahwa sifat dinamis reputasi perusahaan merupakan reaksi pemangku kepentingan pada aktivitas perusahaan yang diinformasikan dan dikomunikasikan. 
Belajar dari para penelitian (Money, Saraeva, Garnelo-Gomez, Pain, \& Hillenbrand, 2017)mengenai perkembangan penelitian pada isu reputasi perusahaan, kita diyakinkan bahwa reputasi perusahaan dimaknai secara berbeda seperti tampak dalam tabel IV.

Tabel IV

Pandangan mengenai Reputasi

\begin{tabular}{|c|c|c|}
\hline No & Periode & Pandangan mengenai reputasi \\
\hline 1 & $\begin{array}{l}1940 \\
1990\end{array}$ & $\begin{array}{lll}\text { 1. } & \text { Reputasi perusahaan } \\
& \text { sebagai aset strategis } \\
\text { 2. } & \text { Reputasi perusahaan } \\
& \text { sebagai sinyal } \\
\text { 3. } & \text { Reputasi perusahaan } \\
& \text { sebagai } \quad \text { pandangan } \\
& \text { company centric }\end{array}$ \\
\hline 2 & $\begin{array}{l}1990 \\
2006\end{array}$ & 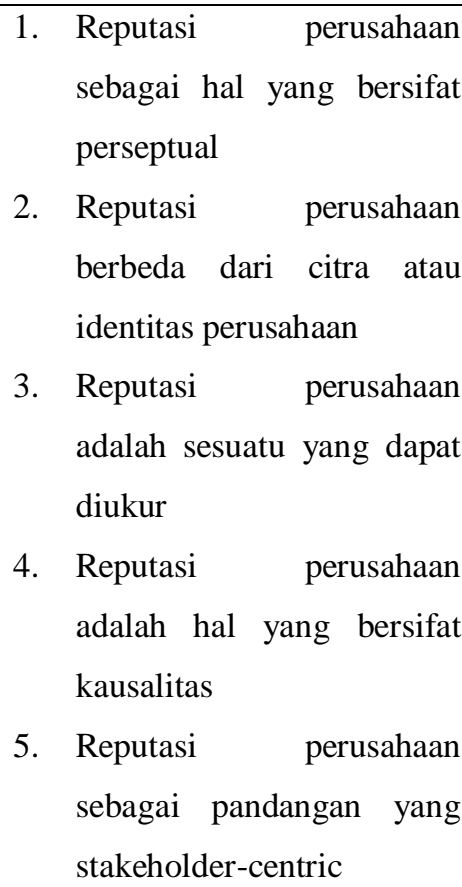 \\
\hline 3 & $\begin{array}{l}2006- \\
\text { sekarang }\end{array}$ & $\begin{array}{l}\text { 1. Reputasi perusahaan } \\
\text { sebagai suatu mekanistik } \\
\text { 2. Reputasi perusahaan } \\
\text { adalah sesuatu hal yang } \\
\text { bersifat kontingensi }\end{array}$ \\
\hline
\end{tabular}

Sumber: Money (2017)

Perkembangan perhatian akademisi mengenai reputasi sosial dapat terlihat dari pendalaman dan cakupan bahasan mengenai reputasi sosial. Tema berawal dari upaya memahami apa itu reputasi, karakteristik reputasi, relasinya dengan konstruk yang lain, cara pandang atas reputasi, hingga bagaimana reputasi terbangun. Reputasi perusahaan sebagai sesuatu yang bersifat kontingensi merupakan perkembangan akhir yang dinyatakan oleh Money(2017). Hal ini hendak menunjukkan bahwa reputasi perusahaan bersifat kontekstual, yaitu reputasi akanditentukan oleh konstruksi lingkungan sosial dimana perusahaan beroperasi (Kobrak, 2013). Dapat dibayangkan, bila sebuah perusahaan beroperasi dalam konteks masyarakat tetapi perusahaan melupakan bahwa ada seperangkat nilai tertentu yang dianutanggota masyarakat, misalnya perusahaan tetap mempekerjakan karyawan meskipun di hari libur keagamaan tertentu. Masyarakat tentu akan menilai perusahaan mengabaikan dan tidak seensitif terhadap nilai yang berlaku di dalam masyarakat. Reputasi perusahaan akan memburuk, dan masyarakat mungkin menjadi enggan bekerja di perusahaan itu, dalam kondisi ekstrim, sangat mungkin masyarakat akan meminta perusahaan 
menghentikan operasi yang berarti perusahaan mengalami delegitimasi atas operasinya dan harus menutup pabriknya. Almeida dan Coelho (2018) memberikan contoh pengaruh reputasi perusahaan pada komitmen kerja dan mungkin juga berpengaruh pada kinerja karyawan.

Dari aspek lain, beberapaakademisi sudahmelakukanrisetmengenairelasiantarar eputasidan kinerjakeuangan (Hussain, 2015; Jain, Vyas, \& Chalasani, 2016; Roberts \& Dowling, 2002).Merekamenemukanrelasipositifantar areputasiperusahaandankinerjakeuangan.M anakala perusahaan menunjukkan sinyalsinyal positif mengenai situasi keuangan perusahaan, maka reputasi perusahaan akan meningkat. Peningkatan ini akan tampak misalnya dari keinginan para investor untuk menanamkan uangnya melalui pembelian saham perusahaan, atau pihak perbankan dipermudah membuat keputusan atas pengajuan kredit karena perusahaan menunjukkan kemampuan keuangannya di dalam laporan keuangan.

Merefleksikan fenomena bahwa reputasi perusahaan menjadi pusat perhatian akademisi, bahwa reputasi berpotensi menciptakan keunggulan bagi perusahaan, bahwa reputasi perusahaan bermanfaat di mata stakeholder secara umum dan bahwa reputasi itu bersifat dinamis dan kontingensi, para akademisi dan praktisi memerlukan pemahaman yang lengkap mengenai konsepsi reputasi perusahaan. Dalam perkembangan konsepsi reputasi perusahaan, banyak penelitian yang sudah dilakukan mengenai relasi reputasi perusahaan dengan ukuranukuran kinerja perusahaan (epistomology) dan pengetahuan berkaitan dengan bagaimana perusahaan harus mengelola reputasi perusahaan agar mendapatkan manfaat positif yang melekat dari reputasi perusahaan (aksiologi). Mempertimbangkan posisi strategis reputasi perusahaan, paper ini berkontribusi dalam memposisikan reputasi perusahaan dalam konteks pendekatan ontologi untuk memberikan jawaban mengenai konstruk reputasi perusahaan.

\section{Pendekatan ontologis pada Reputasi perusahaan}

Ontologi merupakan salah satu cabang dalam ilmu filsafat yang mencoba memahami "being" dan berkenaan dengan "what is" (Crotty, 1998).Blaikie, N. (2010)mengatakanontologisebagai" the science or study of being"danontologiberkaitandenganrealitas( nature of reality).Guna mendapatkan pemahaman mengenai "being" dan "What is", kita dapat mulai dengan menentukan posisidiridalammemandangsuatufenomena 
Di dalam filsafat ontologi dikenal ada dua posisi sentral yaitu obyektif (objectivism) dan subyektif (constructionism), meskipun ada banyak posisi lain yang tidak digunakan dalam paper ini (Al-saadi, 2014).Saunders et al mendeskripsikanObjectivism sebagaikeberadaanposisientitassosial (konsep/fenomena) bersifateksternalterhadapaktorsosial.Brym an, A. (2012)secaralebih formal merumuskanbahwaposisiontologisobyektif adalahpengakuansifatindependensifenome nasosialterhadapaktorsosial.Sifatindepende nsiataueksternalinimemberikankonotasiba hwaaktorsosialmemandangsebuahfenomen asebagaisuatu di luardirinyasehinggapandangannyaakanlebi hobyektif.Posisisentralkeduaadalahsubyekt if (constructionism) yang memandangfenomenasosialtimbuldaripers epsiaktorsosialdantindakankonsistennyabe rkaitandenganfenomenaitu.Aktorsosialmen entukaneksistensifenomenaitu.Sejalandeng anini, Bryman,

A. (2012)memastikanbahwafenomenasosialda nmakna yang terkandung di dalamnyaselaludibentukolehaktorsosial.Ke duaposisisentraliniakandilibatkanuntukme mahamifenomena "reputasi”" perusahaan.

Setiap bisnis di dalam menjalankan operasi bisnis bersentuhan dengan banyak pihak yang akan menentukan keberlangsungan hidup bisnis. Bryson
(2004) menyatakan bahwa pihak-pihak itu adalah pihak yang disebut dengan pemangku kepentingan (stakeholders) dan menegaskan bahwa pihak yang dapat disebut sebagai pemangku kepentingan jika mereka memiliki pengaruh langsung pada masa depan organisasi. Matuleviciene dan Stravinskiene (2015) mengatakan ada empat pemangku kepentingan yang utama, yaitu pemilik, karyawan, pemasok dan konsumen. Mereka adalah pihak yang memiliki pengaruh yang sangat kuat pada keberadaan perusahaan. Sementara itu, masih ada pihak-pihak lain yang berpengaruh pada keberadaan perusahaan meskipun tidak langsung, yaitu lembaga sosial masyarakat (NGO), pemerintah dan masyarakat. Paragraf berikut ini mendiskusikan keempat pemangku kepentingan utama bisnis untuk memberikan konteks reputasi bagi perusahaandalampendekatanontologis.

Pertama, para pemilik perusahaan dan investor memutuskan berinvestasi pada suatu usaha karena mereka mengharapkan kesejahteraan dari investasi yang ditanamkan(Roberts\& Downling, 2002). Dalam kaitannya dengan reputasi perusahaan, kesejahteraan ini mewujud melalui pertumbuhan nilai uangnya. Informasi mengenai pertumbuhan dan potensi pertumbuhan nilai uang tercermin dalam laporan keuangan perusahaan. 
Pemilik dan investor yang rasional akan mengamati perubahan laporan keuangan perusahaan untuk memastikan pertumbuhan nilai uangnya. Laporan keuangan yang disiapkan oleh bagian akuntansi memberikan informasiyang menjadi dasar untuk mengambil keputusan investasi. Setiap orang akan memiliki pendapat yang sama mengenai situasi perusahaan berdasarkan data numerik yang tersedia. Dengan demikian, bila rasio keuangan menunjukkan perusahaan dalam posisi menguntungkan, maka semua pihak juga akan mengatakan hal yang sama. Dalam pandangan ontologi, pemilik dan investor mempertimbangkan secara obyektif semua rasio keuangan yang menjadi pusat perhatiannya. Rasio keuangan memberikan interpretasi relatif sama pada stakeholder yang terkait. Ini memenuhi pandangan ontologi obyektif (objectivism).

Kedua, suplier adalah kategori pemangku kepentingan yang secara langsung mempengaruhi operasi perusahaan. Sebuah model relasi antara perusahaan dengan suplier disampaikan oleh Bendixen dan Abratt (Bendixen \& Abratt, 2013). Kegagalan perusahaan membangun relasi dengan suplier, akan menyulitkan perusahaan dalam memastikan pemenuhan kebutuhan para pelanggannya. Perusahaan mebel kayu, misalnya, membutuhkan pedagang kayu sebagai penyedia bahan mentah yang akan dikonversikan menjadi berbagai jenis furniture yang dibutuhkan oleh masyarakat. Reputasi perusahaan mebelakan menentukan apakah pedagang kayu akan menyerahkan kayu yang dimilikinya. Apakah yang harus dipertimbangkan perusahaan sebagai dasar keputusannya? Tidak berbeda dengan para bankir ketika mempertimbangkan pinjaman kepada para nasabahnya, para pedagang juga melihat pada $5 \mathrm{C}$ (character, capability, capacity, collateral, dan competence). Hanya collateral/jaminan dan capacity dari kelima $\mathrm{C}$ itu yang bersifat objektif. Tiga lainnya lebih banyak bersifat subyektif. Dengan pendekatan ontologis, dapat dinyatakan bahwa reputasi perusahaan dari perspektif suplier cenderung ke subyektif.

Ketiga, konsumen adalah penjamin keberlangsungan hidupperusahaan. Perusahaan tanpa memiliki konsumen, tentu dia tidak akan mendapatkan pendapatan. Fenomena ini sudah diselidiki oleh Salah S. Hassan (Salah S. Hassan, 2009). Dia menemukan adanya perbedaan antara pelanggan dan bukan pelanggan dalam menentukan reputasi perusahaan. Emotional appeal lebih menjadi dimensi yang dipertimbangkan pelanggan untuk menentukan reputasi perusahaan. Emotional appeal yang disampaikan Salah S. Hassan menunjuk pada aspek yang tidak 
obyektif, melainkan subyektif dalam perspektif konsumen. Berdasarkan hal ini, konsumen memandang secara subyektif mengenai dasar dari penilaian reputasi perusahaan yang bersesuaian dengan ontologi subyektif.

Keempat, karyawan perusahaan. Bergeser dari stakeholder utama, pembahasan berikut ini diarahkan pada stakeholder yang mempengaruhi operasi perusahaan meskipun tidak secara langsung, yaitu pemerintah, NGO (LSM) dan masyarakat secara umum. Pemerintah memandang reputasi perusahaan sebagai dasar untuk memutuskan kelayakan operasi perusahaan berdasarkan segala persyaratan yang harus dimiliki perusahaan. Kelengkapan ini bersifat obyektif, misalnya apakah perusahaan memiliki sertifikasi halal misalnya untuk menawarkan produk makanan di Indonesia. Selama perusahaan sudah memiliki sertifikasi halal, maka perusahaan mendapatkan legitimasi untuk menjalankan bisnisnya. Kelengkapan persyaratan ini bersifat obyektif. Dapat dinyatakan bahwa secara ontologis, reputasi perusahaan dari perspektif pemerintah bersifat obyektif. Sementara itu, LSM dan masyarakat memandang reputasi perusahaan berdasarkan persepsi subyektif atas aktivitas yang dijalankan dan dikomunikasikanoleh perusahaan. Subyektivitas tampak mendominasi di dalam membentuk konstruk reputasi perusahaan. Laporan mengenai aktivitas perusahaan yang mencerminkan rasa tanggung jawab secara sosial misalnya, semua bersifat deskriptif dan akan ditangkap secara subyektif baik oleh LSM maupun kelompok masyarakat yang membaca laporan pertanggung jawaban sosial perusahaan. Tidak diragukan lagi, reputasi perusahaan di mata LSM dan masyarakat umum bersifat subyektif dan ini memenuhi kaidah ontologi subyektif.

\section{TabelVI}

RangkumanPerspektifOntologisPemangku Kepentingan

\begin{tabular}{|l|l|}
\hline PemangkuKepentingan & $\begin{array}{l}\text { PerspektifOntolo } \\
\text { gis }\end{array}$ \\
\hline $\begin{array}{l}\text { Pemilik Perusahaan } \\
\text { dan Investor }\end{array}$ & Obyektif \\
\hline Suplier/pemasok & Obyektif \\
\hline Konsumen & Subyektif \\
\hline Karyawan & Subyektif \\
\hline Pemerintah & $\begin{array}{l}\text { ObyektifdanSub } \\
\text { yektif }\end{array}$ \\
\hline $\begin{array}{l}\text { LembagaSwadayaMas } \\
\text { yarakat }\end{array}$ & Subyektif \\
\hline Masyarakatumum & Subyektif \\
\hline
\end{tabular}

\section{SIMPULAN}

Dengan pendekatanstakeholder analysis, penelititelahmeninjaupemangkukepentinga 
$\mathrm{n}$

yang

secaraumummemberikanpengaruhpadaper

usahaan dalam perspektif obyektifdansubyektif. Dari investor misalnya, mereka memandang dan mempersepsikan reputasi perusahaan berdasarkan atribut finansial dari rasiorasio keuangan berdasarkan laporan keuangan perusahaan. Konsumen sebagai stakeholder, mempersepsikan reputasi berusahaan berdasarkan keyakinan yang merefleksikan pengalaman interaksi mereka dengan perusahaan. Masyarakat secara umum, karena tidak bersinggungan langsung dengan perusahaan, tampaknya akan sulit untuk mengkonstruksi reputasi perusahaan. Melalui aktivitas perusahaan seperti CSR, masyarakat berkesempatan untuk berinteraksi langsung dengan perusahaan. Di sinilah proses mengkonstruksi reputasi berlangsung. Perusahaan dapat memanfaatkan media massa untuk membangun reputasi perusahaan.

Dari teori agensi, tampak ada potensi besar munculnya konflik kepentingan di antara stakeholder perusahaan. Pemilik perusahaan dan para karyawan misalnya. Pemilik perusahaan ingin mendapatkankeuntungan yang akan meningkatkan kesejahteraan, sementara gaji yang yang diterima karyawan adalah bagian dari biaya operasional dan pasti akan mengurangi porsi keuntungan bagi pemilik perusahaan.

Dengan demikian, karena reputasi secara ontologis dapat bersifat baik subyektif maupun obyektif, menilai reputasi perusahaan sebagai agregasi dari persepsi semua kelompok stakeholdertidak dapat dilakukan, seperti menjumlahkan 2 apel dan 2 jeruk.Agenda risetkedepan yang menarikuntukdikajilebihmendalamadalahb agaimanamembangunkonstrukreputasiperu sahaandenganmengkombinasikanpendekat an yang obyektifdansubyektif.

\section{DAFTAR PUSTAKA}

Al-saadi, H. (2014). Demystifying Ontology and Epistemology in research methods, (February), 1-11.

Almeida, M. da G. M. C., \& Coelho, A. F. M. (2018). The Antecedents of Corporate Reputation and Image and Their Impacts on Employee Commitment and Performance: The Moderating Role of CSR. Corporate Reputation Review. https://doi.org/10.1057/s41299-0180053-8

Bendixen, M., \& Abratt, R. (2013). Corporate Identity , Ethics and Reputation Russell in Supplier-Buyer Relationships Michad Bendixen Abmtt, 76(1), 69-82. 
Br, D. (2018). CSR Actions in Companies and Perception of Their Reputation by Managers: Analysis in the Rural Area of an Emerging Country in the Banking Sector. https://doi.org/10.3390/su10040920

Brammer, S. and S. Pavelin: 2004, 'Voluntary Social Disclosures by Large UKCompanies', Business Ethics:A European Review 13(2/3), 86-99

Bryman, A. (2008). Social research methods. Oxford:Oxford University Press.

Bryson, J. M. (2004). What to do when stakeholders matter. Stakeholder identification and analysis techniques. Public Management Review, 6(1), 21-53.

http://dx.doi.org/10.1080/1471903041 0001675722

Crotty, M. (1998).The Foundations of Social Research:Meaning and Perspective in the Research Process. London: Sage.

Fombrun, C. J., \& Ponzi, L. J. (2015). Stakeholder Tracking and Analysis: The RepTrak $®$ System for Measuring Corporate Reputation, 18(1), 3-24. https://doi.org/10.1057/crr.2014.21

Gardberg, N. A. (2017). Corporate Reputation: Fashion, Fad, or Phenomenon? Corporate Reputation Review.

https://doi.org/10.1057/s41299-017-

0033-4

Hussain, N. (2015). Nazim Hussain Impact of Sustainability Performance on Financial Performance:An Empirical Study of Global Fortune ( N100 ) Firms, (June).

Illia, L.and Balmer, J.M.T. (2012), "Corporate communication andcorporate marketing", Corporate Communications, Vol. 17 No. 4, pp. 415-433.

Irmaini, Z. (2011). Memperkuat Reputasi Perusahaan Melalui Implementasi CSR, 4(2), 55-70.

Jain, P., Vyas, V., \& Chalasani, D. P. S. (2016). Corporate Social Responsibility and Financial Performance in SMEs: A Structural Equation Modelling Approach. https://doi.org/10.1177/09721509166 30827

Kobrak, C. (2013). The concept of reputation in business history. Business History Review, 87(4), 763- 
786.

https://doi.org/10.1017/S0007680513

00113X

Luijk, H. Van. (2003). Author ( s ): HENK VAN LUIJK Source: Society and Economy , Vol . 25 , No . 2, BUSINESS ETHICS AND ETHICAL BUSINESS Published by: Akadémiai Kiadó Stable URL : https://www.jstor.org/stable/4147196 8, 25(2), 159-170.

Matuleviciene, M., \& Stravinskiene, J. (2015). The importance of stakeholders for corporate reputation. Engineering Economics, 26(1), 7583.

https://doi.org/10.5755/j01.ee.26.1.69 21

Money, K., Saraeva, A., Garnelo-Gomez, I., Pain, S., \& Hillenbrand, C. (2017). Corporate Reputation Past and Future: A Review and Integration of Existing Literature and a Framework for Future Research. Corporate Reputation Review, 20(3-4), 193211. https://doi.org/10.1057/s41299017-0034-3

Olegario, R., \& McKenna, C. (2013). Introduction: Corporate reputation in historical perspective. Business History Review, 87(4), 643-654. https://doi.org/10.1017/S0007680513 001074

Pérez, A. (2015). Corporate reputation and CSR reporting to stakeholders: Gaps in the literature and future lines of research. Corporate Communications, 20(1), 11-29. https://doi.org/10.1108/CCIJ-012014-0003

Quevedo-puente, E. De, Fuente-sabat, J. M. D. la, \& Delgado-Garcia, J. B. (2003). Corporate Social Performance and Corporate Reputation: Two Interwoven Perspectives, 10(1), 6072.

https://doi.org/10.1057/palgrave.crr.1 550038

Roberts, P. W., \& Dowling, G. R. (2002). Corporate Reputation and Sustained Superior Financial Performance Author ( s ): Peter W. Roberts and Grahame R . Dowling Published by : Wiley Stable URL: https://www.jstor.org/stable/3094296 CORPORATE REPUTATION AND SUSTAINED, 23(12), 1077-1093. https://doi.org/10.1002/smj.274

Salah S. Hassan, H. M. S. (2009). Customer and non-customer perspectives for examining corporate 
reputation, $\quad 18(5), \quad 326-337$.

https://doi.org/10.1108/10610420910

981800 